\title{
ОЦІНЮВАННЯ РІВНЯ БІОРІЗНОМАНІТТЯ ТА ПРИРОДНОГО ПОНОВЛЕННЯ ДУБА ЗВИЧАЙНОГО У ЛІСОГОСПОДАРСЬКІЙ ЗОНІ МІСТА ВІННИЦЯ
}

\begin{abstract}
Досліджено рівень біорізноманіття деревно-чагарникових видів та рівень природного поновлення основних лісотвірних порід Вінницького лісового господарства. Встановлено фактори, які впливають на процеси природного поновлення під наметом деревостанів свіжої і вологої грабової діброви. За результатами обстежень виявлено, що під наметом деревостану вплив на самосів дуба звичайного мають не тільки материнські дерева, але й підлісок та живий надгрунтовий покрив. Досліджено, що кількість самосіву під материнським деревостаном значно зменшується в період між насіннєвими роками. Також встановлено, що помірно розвинений живий надгрунтовий покрив позитивно впливає на дубовий самосів на лісосіках, він своїм притіненням пом'якшує різкі зміни мікроклімату. Оцінено вплив підліску на природне поновлення і з'ясовано, що в багатоярусних складних насадженнях різноманітність підліску негативно впливає на розвиток дубового самосіву, особливо це проявляється у віці 1-3 роки. Вивчено процеси природного поновлення в дослідних деревостанах. На більшості ділянок трапляється підріст дуба звичайного, граба звичайного, клена гостролистого та ясена звичайного. Підріст липи дрібнолистої і бука лісового виявлено тільки під наметом окремих деревостанів. За результатами проведених досліджень виявлено, що діброви Поділля мають високий лісовідновний потенціал, який змінюється в межах 65-80\%. Кількість підросту дуба звичайного становить від 10,2 до 52,1 \% від загальної густоти підросту, або близько 2,7-8,9 тис. шт. га ${ }^{-1}$. Вік підросту дуба не перевищує трьох років. У старшому віці його тіньовитривалість зменшується і рослини перетворюються в стирчаки та ги-
\end{abstract} нуть.

Ключові слова: дуб звичайний; світловий режим; природне поновлення; живий надгрунтовий покрив; підлісок.

Вступ. Відновлення цінних популяцій дубових лісостанів складної вертикальної структури - одне із актуальних завдань лісового господарства. Вирішення його пов'язане з проблемою лісовідновлення, яке представляє собою технологічний процес лісогосподарського виробництва, заснований на природних законах зміни поколінь і формування лісових біогеоценозів. Дуб та інші деревні компоненти дубових лісів можуть відновлюватися насінним та вегетативним шляхом. Найбільш продуктивні, біологічно стійкі та довговічні -деревостани дуба насінного походження, на вирощування яких і зосереджено увагу.

Аналіз останніх досліджень і публікацій. У наукових працях більшості радянських вчених наголошувалося про можливість природного поновлення дуба звичайного в українських дібровах та можливість його застосування для потреб лісовідновлення (Neiko \& Martseniuk, 2008; Didenko, 2008; Levchenko, 2006). В умовах України та Вінниччини зокрема, вивченню біотичного різноманіття дубових лісостанів та процесів природного поновлення приділяли увагу такі вчені-лісівники, як: В. Д. Бондаренко, Л. І. Копій, В. Г. Мазепа, І. С. Нейко. Мета дослідження - проаналізувати рівень біотич- ного різноманіття дубових деревостанів та залежність рівня природного поновлення від складу та віку материнського насадження, дослідити вплив підліску та живого надгрунтового покриву на ріст і розвиток сіянців дуба звичайного.

Результати дослідження та їх обговорення. Процес насінного відновлення дубових деревостанів складається із таких обов'язкових етапів: плодоношення дерев; поява самосіву і перехід його у стан підросту; рубка материнського деревостану і вплив її на збереження та якість підросту; заходи зі сприяння природному відновленню зрубів. На кожному із цих етапів $є$ сприятливi, або негативні умови для росту і розвитку молодого покоління лісу, які можуть посилюватися лісогосподарськими заходами. Потенційні можливості появи самосіву дуба часто обмежені тривалими періодами між добрими і рясними плодоношеннями дуба та знищення жолудів шкідниками. Однак під наметом стиглого дубового деревостану постійно $є$ його самосів, кількість якого між насіннсвими роками зменшується (Bondarenko, Kuziv \& Kopii, 1985; Kopyi, 1986).

Ріст дубового самосіву пришвидшується, або затримується залежно від світлового режиму під наметом де-

\section{Інформація про авторів:}

Матусяк Михайло Васильович, канд. с.-г. наук, ст. викладач, кафедра садово-паркового господарства, садівництва та виноградарства. Email: mikhailo1988@gmail.com; https://orcid.org/0000-0001-8099-7290

Циганська Олена Іванівна, канд. с.-г. наук, ст. викладач, кафедра садово-паркового господарства, садівництва та виноградарства. Email: lenkatsiganskaya@gmail.com; https://orcid.org/0000-0002-4046-1034

Цитування за ДСту: Матусяк М. В., Циганська О. І. Оцінювання рівня біорізноманіття та природного поновлення дуба звичайного у лісогосподарській зоні міста Вінниця. Науковий вісник НлтУ України. 2018, т. 28, № 8. С. 56-60.

Citation APA: Matusiak, M. V., \& Tsyhanska, O. I. (2018). Evaluation of the level of biodiversity and natural regeneration of common oak in the forest zone of Vinnytsia. Scientific Bulletin of UNFU, 28(8), 56-60. https://doi.org/10.15421/40280811 
ревостанів чи на зрубах. На його розвиток значно впливає не тільки материнський деревостан, але й підлісок. У цьому сенсі найнесприятливіші умови для збереження самосіву дуба створюються у складних багатоярусних деревостанах $з$ добре розвиненим підліском. У цих умовах самосів дуба не виживає більше 2-3 років.

Помірно розвинений трав'яний покрив позитивно впливає на стан самосіву на лісосіках. Він своїм притіненням пом'якшує різкі зміни мікроклімату. Дуб, як відомо, характеризується добре вираженою здатністю до утворення порослі. Така його властивість до порослевого відновлення зберігається впродовж тривалого часу після проведення рубки та визначається умовами місцезростання. 3 господарської точки зору, використання порослевого відновлення також вигідне, оскільки воно пов'язане зі значно меншими трудовими і матеріальними затратами та із більшою вірогідністю гарантує успішність виконання лісовідновлювальних робіт. Негативними якостями вегетативного покоління лісу $є$ зниження його довговічності, товарності та продуктивності. Тому потрібно лісовідновлювальні заходи спрямувати на поступову заміну деревостанів порослевого походження на насінні (Kopii, 2010; Mazepa \& Krynytska, 2012).

Табл. 1. Лісівничо-таксаційні показники деревостанів в умовах ДП "Вінницьке лісове господарство" (2016 р.)

\begin{tabular}{|c|c|c|c|c|c|c|c|c|c|c|c|}
\hline \multirow{2}{*}{$\begin{array}{l}\text { № } \\
\text { пр. } \\
\text { пл. }\end{array}$} & \multicolumn{2}{|c|}{ Ординати } & \multirow{2}{*}{$\begin{array}{c}\text { Висота } \\
\text { н.р.м., м }\end{array}$} & \multirow[b]{2}{*}{ Склад деревостану } & \multirow{2}{*}{$\begin{array}{l}\text { Індекс } \\
\text { типу } \\
\text { лісу }\end{array}$} & \multirow{2}{*}{$\begin{array}{c}\text { Вік дере- } \\
\text { востану, } \\
\text { років }\end{array}$} & \multirow{2}{*}{$\begin{array}{c}\text { Висота, } \\
\text { м }\end{array}$} & \multirow{2}{*}{$\underset{\text { см }}{\text { Діаметр, }}$} & \multirow{2}{*}{$\begin{array}{c}\text { Боні- } \\
\text { тет }\end{array}$} & \multirow{2}{*}{$\begin{array}{c}\text { Повно- } \\
\text { та }\end{array}$} & \multirow{2}{*}{$\begin{array}{l}\text { Запас, } \\
\text { м }^{3} \cdot \mathrm{ra}^{-1}\end{array}$} \\
\hline & пн. широта & $\begin{array}{c}\text { сх. довго- } \\
\text { та }\end{array}$ & & & & & & & & & \\
\hline 1 & $49^{\circ} 15,530$ & $28^{\circ} 25,896$ & 266,0 & 5Дз2Яз3Гз+ЛпдКлг & $\mathrm{D}_{2}$-гД & 71 & $\overline{24,2}$ & 26,4 & $\mathrm{I}$ & 0,68 & 290 \\
\hline 2 & $49^{\circ} 15,338$ & $28^{\circ} 25,869$ & 271,0 & 6Дз3Гз1Яз+КлгВзг & $\mathrm{D}_{2}$-гД & 61 & 22,4 & 26,1 & $\mathrm{I}$ & 0,70 & 256 \\
\hline 3 & $49^{\circ} 15,355$ & $28^{\circ} 25,955$ & 272,0 & 4Яз4Гз1Дз1Лпд+КлгКля & $\mathrm{D}_{2}$-гД & 76 & 25,6 & 26,1 & $\mathrm{I}$ & 0,70 & 268 \\
\hline 4 & $49^{\circ} 15,282$ & $28^{\circ} 25,890$ & 274,0 & 6Яз3Гз1Лпд & $\mathrm{D}_{2}$-гД & 81 & 25,1 & 28,3 & $\mathrm{I}$ & 0,69 & 305 \\
\hline 5 & $49^{\circ} 15,202$ & $28^{\circ} 25,834$ & 274,0 & 5Яз3Гз2Лпд+КлгВзгКля & $\mathrm{D}_{2}$-гД & 91 & 26,0 & 30,2 & I & 0,80 & 331 \\
\hline 6 & $49^{\circ} 15,074$ & $28^{\circ} 25,739$ & 271,0 & 6Гз1Ялє1Лпд2Яз & $\mathrm{D}_{2}$-гД & 46 & 16,5 & 18,3 & II & 0,71 & 150 \\
\hline 7 & $49^{\circ} 15,022$ & $28^{\circ} 25,662$ & 274,0 & 4Яз4Гз1Дз1Лпд & $\mathrm{D}_{3}$-гД & 96 & 28,3 & 30,4 & $\mathrm{I}$ & 0,68 & 302 \\
\hline 8 & $49^{\circ} 14,858$ & $28^{\circ} 25,441$ & 275,0 & 5Яз4Гз1Клг+ЛпдДзМдє & $\mathrm{D}_{2}$-гД & 111 & 29,1 & 44,0 & I & 0,80 & 389 \\
\hline 9 & $49^{\circ} 14,802$ & $28^{\circ} 25,418$ & 278,0 & 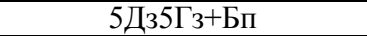 & $\mathrm{D}_{3}$-гД & 46 & 17,3 & 20,2 & $\mathrm{I}$ & 0,70 & 159 \\
\hline 10 & $49^{\circ} 14,548$ & $28^{\circ} 25,367$ & 279,0 & 6Дз3Гз1Лпд+ЯзЧшВзг Клг & $\mathrm{D}_{2}$-гД & 55 & 21,7 & 24,3 & I & 0,74 & 235 \\
\hline 11 & $49^{\circ} 14,452$ & $28^{\circ} 25,317$ & 279,5 & $10 Д 3+\Gamma 3$ & $\mathrm{D}_{2}$-гД & 76 & 29,8 & 28,3 & Ia & 0,77 & 425 \\
\hline 12 & $49^{\circ} 14,272$ & $28^{\circ} 25,300$ & 280,5 & 5Дз5Гз+Бп+Лпд & $\mathrm{D}_{3}$-гД & 56 & 19,2 & 22,0 & I & 0,80 & 218 \\
\hline 13 & $48^{\circ} 14,385$ & $27^{\circ} 25,649$ & 268,0 & 10Ялє & $\mathrm{D}_{2}$-гД & 55 & 20,5 & 24,2 & $\mathrm{I}$ & 0,70 & 276 \\
\hline 14 & $48^{\circ} 14,238$ & $27^{\circ} 25,567$ & 271,0 & 10 Бкл+Гз & $\mathrm{D}_{2}$-гД & 60 & 21,1 & 22,0 & $\mathrm{I}$ & 0,60 & 164 \\
\hline 15 & $48^{\circ} 14,147$ & $27^{\circ} 25,385$ & 269,0 & 6Дз4Гз+Клг & $\mathrm{D}_{2}$-гД & 65 & 19,3 & 26,0 & II & 0,70 & 190 \\
\hline 16 & $48^{\circ} 14,280$ & $27^{\circ} 25,635$ & 272,0 & 10Мдє & $\mathrm{D}_{2}$-гД & 60 & 20,2 & 24,4 & $\mathrm{I}$ & 0,72 & 145 \\
\hline 17 & $48^{\circ} 14,136$ & $27^{\circ} 25,368$ & 270,0 & 7Дч3Гз & $\mathrm{D}_{2}$-гД & 50 & 18,8 & 22,7 & $\mathrm{I}$ & 0,70 & 190 \\
\hline 18 & $48^{\circ} 14,320$ & $27^{\circ} 25,784$ & 270,0 & 9Гз1Клг+Кля & $\mathrm{D}_{2}$-гД & 60 & 17,4 & 20,2 & III & 0,83 & 124 \\
\hline
\end{tabular}

Примітка: Дз - дуб звичайний, Дч - дуб червоний, Яз - ясен звичайний, Клг - клен гостролистий, Кля - клен-явір, Лпд - липа дрібнолиста, Ялє - ялина європейська, Бкл - бук лісовий, Гз - граб звичайний, Чш - черешня (вишня лісова), Взг - в'яз голий.

Нижче наведено детальнішу характеристику лісостанів для кожної пробної площі маршруту дослідження. Деревостан на першій пробній площі має вік 71 рік, повноту 0,68, запас стовбурової деревини $290 \mathrm{~m}^{3} \cdot \mathrm{ra}^{-1}$ та двохярусну вертикальну структуру. Перший ярус утворили дуб звичайний, ясен звичайний, клен гостролистий, а другий - граб звичайний. Підлісок - середньої густоти, який формує ліщина, свидина, бруслина європейська. Зімкнутість трав'яного покриву становить 0,5 . Він представлений маренкою запашною, медункою темною, купиною багатоквітковою, гравілатом міським, копитняком європейським, кропивою глухою, чиною весняною, фіалкою запашною, зірочником ланцетолистим (рис. 1,a).

На другій пробній площі 61-річний деревостан також двохярусний. Його склад становить 6Дз3Гз1Яз+КлгВзг, повнота 0,70 , запас $256 \mathrm{~m}^{3} \cdot \mathrm{ra}^{-1}$. Перший ярус представлений дубом і ясенем. У другому ярусі росте
Ми дослідили процеси природного поновлення під наметом деревостанів свіжої і вологої грабової діброви, які закладено в Якушинецькому (пр. пл. 1-4), Прибузьництвах ДП "Вінницьке лісове господарство". Лісівничо-таксаційні показники деревостанів та географічні точки розміщення дослідних ділянок наведено в табл. 1.

Згідно 3 даними табл. 1, дослідні деревостани мають вік від 46 до 111 років та характеризуються різною часткою дуба звичайного у їх складі. Тут є деревостани, в яких дуб трапляється від поодиноких дерев (пр. пл. 8) до чистого дубняку (пр. пл. 11). В умовах свіжої і вологої грабової діброви трапляються також деревостани без участі дуба звичайного (пр. пл. 4, 5, 6, 7). У таких деревостанах зазвичай переважає ясен звичайний, рідше граб. У складі деревостанів $є$ також клени гостролистий і явір, в'яз голий, липала серцелиста, береза повисла тощо. Загалом у лісовому фонді внаслідок антропогенного впливу значною мірою представлені похідні деревостани. Переважно вони ростуть за першим класом бонітету та мають повноту $0,70-0,80$. Низку дослідних ділянок (пр. пл. 13, 14 і 16, 17) підібрали у похідних та одну (пр. пл. 15) в корінних деревостанах, які підпорядковано ботанічному саду "Поділля" ВНАУ кому (пр. пл. 5-8) і Вороновицькому (пр. пл. 9-12) ліс- 
ярусі. Деревостан характеризується повнотою 0,69 і запасом стовбурової деревини $305 \mathrm{~m}^{3} \cdot \mathrm{ra}^{-1}$. Підлісок середньої густоти утворюють бузина чорна і ліщина. Трав'яний покрив має зімкнутість 0,85 . У його складі поширені яглиця звичайна, кропива дводомна, гравілат міський, герань Роберта, маренка запашна, зірочник ланцетолистий, розхідник звичайний.
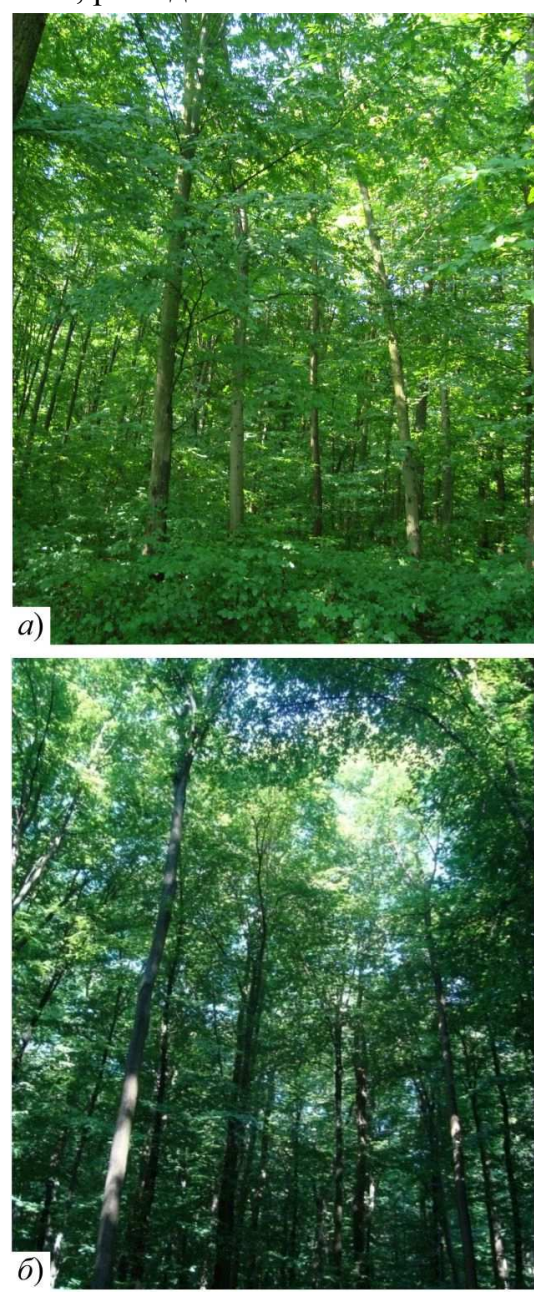

Pис. 1. Дубово-ясеневий деревостан на пробній площі 1 (a) i площі 3 (б)

На пробній площі 5 сформувався 91-річний двохярусний деревостан з ясенем, і липою у верхньому ярусі. Такі види, як граб, клени гостролистий, явір та в'яз утворили другий ярус лісового намету. Повнота деревостану висока $(0,80)$, а запас становить $331 \mathrm{~m}^{3} \cdot \mathrm{ra}^{-1}$. Деревні види ростуть за першим класом бонітету. Підлісок середньої густоти утворили бузина і ліщина. Трав'яний покрив представлений перстачем, підмаренником чіпким, гравілатом міським, анемоною жовтицевою, осокою волосистою, кропивою глухою, бальзаміном, фіалкою звичайною.

Деревостан на пробній площі 6 віком 46 років i складом 6Гз1Ялє1Лпд2Яз виявився одноярусний. Його повнота становить 0,71 , а запас - всього $150 \mathrm{~m}^{3} \cdot \mathrm{ra}^{-1}$. Деревні види в умовах свіжої грабової діброви ростуть за другим класом бонітету. Підлісок відсутній. Трав'яний покрив має зімкнутість 0,60. Він представлений копитняком європейським, гравілатом міським, осокою, розхідником звичайним, зубницею (рис. 2).

На пробній площі 7 в умовах вологої грабової діброви сформувався 96-річний двохярусний деревостан 3 породним складом 4Яз4Гз1Дз1Лпд. Він має повноту
0,68 і запас деревини $302 \mathrm{~m}^{3} \cdot \mathrm{ra}^{-1}$. Перший ярус утворили ясен і дуб звичайний, а другий - граб і липа. У підліску поодиноко трапляється бузина чорна. Трав'яний покрив характеризується зімкнутістю 0,5 і представлений гравілатом міським, маренкою запашною, яглицею звичайною, фіалкою звичайною, копитняком європейським, розхідником звичайним.

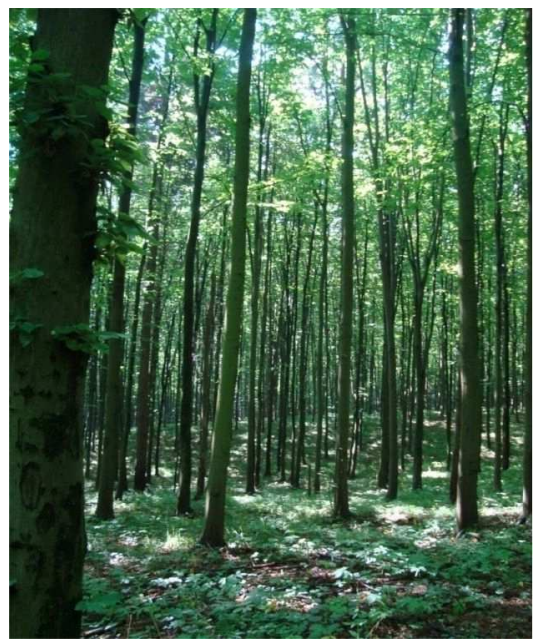

Рис. 2. Ясенево-грабовий деревостан на пробній площі 6

Деревостан на пробній площі 8 виявився 111-річного віку та характеризується двохярусною вертикальною структурою. Його повнота становить 0,80 , а запас деревини - $389 \mathrm{~m}^{3} \cdot \mathrm{ra}^{-1}$. Перший ярус сформували дуб і ясен звичайний $з$ домішкою модрини європейської, а другий - граб, клен гостролистий і липа. Підлісок рідкий і складається 3 поодиноких кущів ліщини. Трав'яний покрив зімкнутістю 0,6 містить анемону жовтицеву, підмаренник чіпкий, осоку волосисту, маренку запашну, гравілат міський, яглицю звичайну і осоку.

Результати вивчення процесів природного поновлення в дослідних деревостанах наведено в табл. 2.

Табл. 2. Кількість самосіву і підросту в лісостанах, тис. штт. $\cdot$ ra $^{-1}$

\begin{tabular}{|c|c|c|c|c|c|c|c|c|}
\hline \multirow{2}{*}{\begin{tabular}{|l|} 
№ \\
пр. \\
пл.
\end{tabular}} & \multirow[b]{2}{*}{ Вид } & \multicolumn{4}{|c|}{ Вік підросту, років } & \multicolumn{2}{|r|}{ Разом } & \multirow{2}{*}{$\begin{array}{c}\text { Середня } \\
\text { висота, } \\
\text { см }\end{array}$} \\
\hline & & 1 & $2-3$ & $4-8$ & $9-15$ & $\begin{array}{l}\text { фак- } \\
\text { тична }\end{array}$ & \begin{tabular}{|c|} 
У перерах. на \\
4-8 річний \\
\end{tabular} & \\
\hline 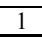 & 2 & 3 & 4 & 5 & 6 & 7 & 8 & 9 \\
\hline \multirow[t]{4}{*}{1} & Д3 & 0,8 & 0,9 & - & - & 1,7 & 0,8 & 11 \\
\hline & Яз & 0,4 & 0,7 & - & - & 1,1 & 0,6 & 9 \\
\hline & Клг & - & 0,2 & 0,3 & 0,1 & 0,6 & 0,6 & 14 \\
\hline & $\Gamma 3$ & - & 0,4 & 0,8 & 1,0 & 2,2 & 2,7 & 45 \\
\hline \multicolumn{2}{|c|}{ Разом } & 1,2 & 2,2 & 1,1 & 1,1 & 5,6 & 4,7 & \\
\hline \multirow{4}{*}{2} & Д3 & 0,9 & 0,7 & - & - & 1,6 & 0,7 & 10 \\
\hline & Я $_{3}$ & 0,1 & 0,3 & - & - & 0,4 & 0,2 & 11 \\
\hline & Клг & 0,1 & 0,2 & 0,3 & 0,2 & 0,8 & 0,8 & 45 \\
\hline & $\Gamma 3$ & - & 0,1 & 0,4 & 0,7 & 1,2 & 1,6 & 52 \\
\hline & a30m & 1,1 & 1,3 & 0,7 & 0,9 & 4,0 & 3,3 & \\
\hline \multirow{4}{*}{3} & Д3 & 0,5 & 0,1 & - & - & 0,6 & 0,2 & 9 \\
\hline & Яз $_{3}$ & 0,4 & 1,2 & 0,2 & - & 1,8 & 1,1 & 7 \\
\hline & Лпд & - & - & 0,3 & - & 0,3 & 0,3 & 24 \\
\hline & $\Gamma 3$ & - & 0,9 & 1,6 & 0,7 & 3,2 & 3,4 & 41 \\
\hline \multicolumn{2}{|c|}{ Разом } & 0,9 & 2,2 & 2,1 & 0,7 & 5,9 & 5,0 & \\
\hline & Д3 & 0,2 & 0,4 & - & - & 0,6 & 0,3 & 8 \\
\hline \multirow[t]{2}{*}{4} & $Я_{3}$ & 1,0 & 0,5 & 0,2 & - & 1,7 & 0,8 & 12 \\
\hline & $\Gamma 3$ & - & 1,3 & 1,5 & 0,5 & 3,3 & 3,2 & 37 \\
\hline \multicolumn{2}{|c|}{ Разом } & 1,2 & 2,2 & 1,7 & 0,5 & 5,6 & 4,3 & \\
\hline & Д3 & 0,8 & 0,6 & - & - & 1,4 & 0,6 & 10 \\
\hline \multirow[t]{2}{*}{5} & Клг & - & - & 0,4 & 0,5 & 0,9 & 1,2 & 35 \\
\hline & Г3 & 0,3 & 1,1 & 0,5 & 0,4 & 2,3 & 2,0 & 28 \\
\hline \multicolumn{2}{|c|}{ Разом } & 1,1 & 1,7 & 0,9 & 0,9 & 4,6 & 3,8 & \\
\hline & Я3 & 0,2 & 0,6 & - & - & 0,8 & 0,5 & 11 \\
\hline
\end{tabular}




\begin{tabular}{|c|c|c|c|c|c|c|c|c|}
\hline 1 & 2 & 3 & 4 & 5 & 6 & 7 & 8 & 9 \\
\hline \multirow[t]{3}{*}{6} & Клг & 0,1 & 0,2 & 0,1 & - & 0,4 & 0,3 & 19 \\
\hline & Лпд & - & - & 0,2 & - & 0,2 & 0,2 & 15 \\
\hline & \begin{tabular}{|l|}
$\Gamma_{3}$ \\
\end{tabular} & - & \begin{tabular}{|l|}
0,7 \\
\end{tabular} & 1,6 & 0,5 & 2,8 & 2,9 & 26 \\
\hline \multicolumn{2}{|c|}{ Разом } & 0,3 & 1,5 & 1,9 & 0,5 & 4,2 & 3,9 & \\
\hline & Д3 & \begin{tabular}{|l|}
0,8 \\
\end{tabular} & 0,4 & - & - & 1,2 & 0,5 & 10 \\
\hline \multirow[t]{2}{*}{7} & Я $_{3}$ & \begin{tabular}{|l|}
0,7 \\
\end{tabular} & 1,9 & 0,4 & - & 3,0 & 1,9 & 12 \\
\hline & $\Gamma 3$ & - & 0,8 & $\begin{array}{ll}0,7 \\
\end{array}$ & 0,3 & 1,8 & 1,7 & 23 \\
\hline \multicolumn{2}{|c|}{ Разом } & 1,5 & 3,1 & 1,1 & 0,3 & 6,0 & 4,1 & \\
\hline \multirow{2}{*}{8} & Д3 & \begin{tabular}{l|l|}
1,4 \\
\end{tabular} & 1,1 & - & - & 2,5 & 1,1 & 9 \\
\hline & $\Gamma 3$ & - & - & 1,6 & 0,7 & 2,3 & 2,7 & 33 \\
\hline \multicolumn{2}{|c|}{ Разом } & \begin{tabular}{|l|}
1,4 \\
\end{tabular} & 1,1 & 1,6 & 0,7 & 4,8 & 3,8 & \\
\hline & Д3 & 1,0 & 0,7 & 0,1 & - & 1,8 & 0,8 & 11 \\
\hline \multirow[t]{3}{*}{9} & Яз & 0,4 & 0,4 & 0,1 & - & 0,9 & 0,5 & 12 \\
\hline & Лпд & - & 0,1 & 0,3 & 0,1 & 0,5 & 0,5 & 16 \\
\hline & $\Gamma 3$ & - & - & 1,1 & 0,3 & 1,4 & 1,6 & 29 \\
\hline \multicolumn{2}{|c|}{ Разом } & \begin{tabular}{|l|}
1,4 \\
\end{tabular} & 1,2 & 1,6 & 0,4 & 4,6 & 3,4 & \\
\hline & Д3 & 1,2 & 0,7 & 0,2 & - & 2,1 & 0,9 & 13 \\
\hline \multirow[t]{2}{*}{10} & Клг & - & - & 0,5 & - & 0,5 & 0,5 & 26 \\
\hline & $\Gamma_{3}$ & - & 0,9 & 0,6 & 1,2 & 2,7 & 3,2 & 31 \\
\hline \multicolumn{2}{|c|}{ Разом } & 1,2 & 1,6 & 1,3 & 1,2 & 5,3 & 4,6 & \\
\hline & Д3 & 1,2 & 0,5 & 0,2 & - & 1,9 & 0,8 & 12 \\
\hline \multirow[t]{2}{*}{11} & Я3 & - & 0,2 & 0,1 & - & 0,3 & 0,2 & 14 \\
\hline & $\Gamma 3$ & - & - & 0,1 & 0,4 & 0,5 & 0,7 & 36 \\
\hline \multicolumn{2}{|c|}{ Разом } & 1,2 & 0,7 & 0,4 & 0,4 & 2,7 & 1,8 & \\
\hline \multirow{2}{*}{12} & Д3 & 1,1 & 1,0 & 0,6 & 2,7 & 5,4 & 5,8 & 16 \\
\hline & $\Gamma_{3}$ & - & - & 2,4 & 1,6 & 4,0 & 5,0 & 25 \\
\hline \multicolumn{2}{|c|}{ Разом } & \begin{tabular}{|l|}
1,1 \\
\end{tabular} & 1,0 & 3,0 & 4,3 & 9,4 & 10,8 & \\
\hline 13 & - & - & - & - & - & - & - & \\
\hline \multirow{2}{*}{14} & Бкл & 1,2 & 1,9 & 0,4 & - & 3,5 & 2,0 & 19 \\
\hline & $\Gamma 3$ & & & 0,1 & - & 0,1 & 0,1 & 28 \\
\hline \multicolumn{2}{|c|}{ Разом } & 1,2 & 1,9 & 0,5 & - & 3,6 & 2.1 & \\
\hline & Д3 & 2,0 & 0,1 & & & 2,1 & 0,5 & 8 \\
\hline \multirow[t]{2}{*}{15} & Клг & & & 0,4 & & 0,4 & 0,4 & 24 \\
\hline & Г3 & & 0,2 & 0,9 & & 1,1 & 1,0 & 26 \\
\hline \multicolumn{2}{|c|}{ Разом } & 2,0 & 0,3 & 1,3 & & 3,6 & 1,9 & \\
\hline \multirow[t]{2}{*}{16} & - & - & - & - & - & - & - & \\
\hline & Д3 & 0,8 & 0,3 & & & 1,1 & 0,4 & 7 \\
\hline 17 & $\Gamma 3$ & 0,4 & 0,6 & 0,8 & & 1,8 & 1,3 & 34 \\
\hline \multicolumn{2}{|c|}{ Разом } & \begin{tabular}{|l|}
1,2 \\
\end{tabular} & 0,9 & 0,8 & & 2,9 & 1,7 & \\
\hline & \begin{tabular}{|l|}
$\Gamma_{3}$ \\
\end{tabular} & \begin{tabular}{|l|}
1,3 \\
\end{tabular} & 1,7 & 3,5 & 1,2 & 7,7 & 6,9 & 36 \\
\hline \multirow[t]{3}{*}{18} & Клг & & 0,4 & 0,5 & & 0,9 & 0,8 & 27 \\
\hline & Кля & & & 0,3 & & 0,3 & 0,3 & 29 \\
\hline & Разом & 1,3 & 2,1 & 4,3 & 1,2 & 8,9 & 8,0 & \\
\hline
\end{tabular}

Згідно з даними табл. 2 під наметом дослідних деревостанів знаходиться від 2,7 до 8,9 тис. шт. га $^{-1}$ самосіву і підросту деревних видів, що у перерахунку на благо- надійний 4-8-річний підріст становить $1,8-10,8$ тис. шт. га $^{-1}$. Тільки під наметом чистого 55-річного ялинового деревостану підросту деревних видів не виявлено. На більшості ділянок трапляється підріст дуба звичайного, граба звичайного, клена гостролистого і ясена звичайного. Підріст липи дрібнолистої і бука лісового виявлено тільки під наметом окремих деревостанів.

Висновки. За результатами проведених досліджень виявлено, що діброви Поділля мають високий лісовідновний потенціал, який змінюється в межах 65-80\%. Кількість підросту дуба звичайного становить від 10,2 до $52,1 \%$ від загальної густоти підросту, або близько 2,7-8,9 тис. шт. га $^{-1}$. Вік підросту дуба не перевищує трьох років. У старшому віці його тіньовитривалість зменшується і рослини перетворюють у стирчаки та гинуть.

\section{Перелік використаних джерел}

Bondarenko, V. D., Kuziv, R. F., \& Kopii, L. I. (1985). Naturally oak in the back of a forest-steppe URSR. Forestry, Forest, Paper and Woodworking Industry, 4, 20-24. Lviv. [In Ukrainian].

Didenko, M. M. (2008). The state of the natural renewal of oak is under the parent tree. Lisivnytstvo $i$ ahrolisomelioratsiia, 113, 186190. Kharkiv: UkrNDILHA. [In Ukrainian].

Kopii, S. L. (2010). Features of natural regeneration of indigenous tree stands in hornbeam of the western region of Ukraine. Abstract of Doctoral Dissertation for Agricultural Sciences (06.03.03 - Silvics and Forestry). Lviv, 20 p. [In Ukrainian].

Kopyi, L. Y. (1986). Safety and growth of self-seeding in clearings of the western forest-steppe. Lesnaia heobotanyka y byolohyia drevesnykh, 63-67. Briansk. [In Russian].

Levchenko, V. V. (2006). Natural seed propagation in fresh otters of the northern part of the right-bank forest steppe. Abstract of Doctoral Dissertation for Agricultural Sciences (06.03.03 - Silvics and Forestry). Kyiv, 19 p. [In Ukrainian].

Mazepa, V. H., \& Krynytska, O. H. (2012). Productivity and condition of reproduced by natural seed by tree stands in hornbeam pine forests of Lviv Roztochchya. Scientific Bulletin of UNFU, 22(9), 14-18. [In Ukrainian].

Neiko, I. S., \& Martseniuk, O. P. (2008). Assessment of the condition of forest ecosystems in the context of balanced forest management and preservation of the stability of agrolandscapes of Ukraine. Scientific Bulletin of UNFU, 18(10), 65-71. [In Ukrainian].

Винницкий национальный аграрный университет, г. Винница, Украина

\section{ОЦЕНКА УРОВНЯ БИОРАЗНООБРАЗИЯ И ЕСТЕСТВЕННОГО ВОЗОБНОВЛЕНИЯ ДУБА ОБЫКНОВЕННОГО В ЛЕСОХОЗЯЙСТВЕННОЙ ЗОНЕ ГОРОДА ВИННИЦА}

Исследован уровень биоразнообразия древесно-кустарниковых видов и уровень естественного возобновления основных лесообразующих пород Винницкого лесного хозяйства. Установлены факторы, влияющие на процессы естественного возобновления под пологом древостоев свежей и влажной грабовой дубравы. В результате обследований обнаружено, что под навесом древостоя влияние на самосев дуба обыкновенного имеют не только материнские деревья, но и подлесок и живой напочвенный покров. Доказано, что количество самосева под материнским древостоем значительно уменьшается в период между семенными годами. Также установлено, что умеренно развитый живой напочвенный покров положительно влияет на дубовый самосев на лесосеках, он своим притенением смягчает резкие изменения микроклимата. Также оценено влияние подлеска на естественное возобновление и установлено, что в многоярусных сложных насаждениях разнообразие подлеска негативно влияет на развитие дубового самосева, особенно это проявляется в возрасте 1-3 года. Изучены процессы естественного возобновления в исследуемых древостоях. На большинстве участков встречается подрост дуба обыкновенного, граба обыкновенного, клена остролистного и ясеня обыкновенного. Подрост липы мелколистной и бука лесного обнаружен только под навесом отдельных древостоев. В результате проведенных исследований установлено, что дубравы Подолья имеют высокий лесовосстановительный потенциал, который колеблется в пределах $65-80$ \%. Количество подроста дуба обыкновенного составляет от 10,2 до 52,1 \% от общей плотности подроста, то есть около 2,7-8,9 тыс. шт. га $^{-1}$. Возраст подроста дуба не превышает трех лет. В более старшем возрасте его устойчивость к затенению уменьшается и растения превращаются в торчки и погибают.

Ключевые слова: дуб обычный; световой режим; естественное возобновление; живой напочвенный покров; подлесок.

Науковий вісник НЛтУ України, 2018, т. 28, № 8 Scientific Bulletin of UNFU, 2018, vol. 28, no 8 


\section{EVALUATION OF THE LEVEL OF BIODIVERSITY AND NATURAL REGENERATION} OF COMMON OAK IN THE FOREST ZONE OF VINNYTSIA

The main objective of the study was to determine the level of biodiversity of the trees and shrubs and the level of natural regeneration of the main forest species of Vinnytsya forestry. In course of the research, a number of factors that influence the processes of natural regeneration under the shadow of forest stand and wet hornbeam wood have been identified. As a result of surveys, self-sown common oaks are found to be influenced not only by the parent trees, but also undergrowth and living surface layer under the shadow of a forest stand. It is revealed that the number of self-sown trees under the parent tree stands significantly decreases during the period between seeding years. Furthermore, the moderately developed living surface layer is defined to affect positively the self-sown common oak on the forest felling, and to mitigate the sharp changes in the microclimate with its shade. We have also evaluated the effect of the undergrowth on the natural regeneration. In the multi-layer complex plantations, the diversity of undergrowth is adversely affected by the development of the self-sown common oak, which is especially manifested at the age of 1-3 years. The processes of natural regeneration in the experimental tree stands have been studied. The vast majority of sites have got undergrowth of common oak, common hornbeam, Norway maple and common ash. Undergrowth of small-leaved lime and common beeches found only under the shadow in some forest stands. In the result of our research we have discovered that the woodlands of Podillya have a high potential of forest regeneration, which varies within $65-80 \%$. The amount of common oak undergrowth usually varies within $10.2-52.1 \%$ of the total density of undergrowth, that is about $2.7-8.9$ thousand pcs. ha $^{-1}$. The age of the common oak undergrowth does not exceed three years. At the older age, its shadow tolerance decreases and plants turn into sticks and die.

Keywords: common oak; light regime; natural regeneration; live surface layer; undergrowth. 